\title{
Online English Learning for Mechanical Engineering Students during the Pandemic: Challenges and Suggestions
}

\author{
Yulima Melsipa Lingga', Karolina ${ }^{2}$ \\ ${ }^{1}$ Department of Mechanical Engineering, Politeknik Negeri Tanah Laut, Indonesia \\ ${ }^{2}$ Department of Economics and Business, Politeknik Negeri Tanah Laut, Indonesia
}

\begin{tabular}{l} 
Article Info \\
\hline Article history: \\
Received Oct 12, 2021 \\
Revised Dec 10, 2021 \\
Accepted Dec 25, 2021 \\
\hline
\end{tabular}

\section{Keywords:}

Online

English

Learning

Challenges

Suggestions

\begin{abstract}
The COVID-19 pandemic has brought changes to the whole world. This pandemic also has an impact on the learning system in Indonesia. From the previous face-to-face learning, to online learning, including for English courses. This study aims to elaborate what challenges were faced by students during online English learning, and what suggestions were given to face and solve these challenges. The object of this research was the first semester students of Mechanical Engineering at the Tanah Laut State Polytechnic. There were 33 students in the Mechanical Engineering department. By using qualitative research methods from written response data and semi-structured interviews, the results showed that there were challenges in the form of unstable or poor internet connections, sudden power outages, lack of interest in learning, and even running out of internet quota while studying. Students also suggested that each material had a learning video that could be replayed at home. They also suggested giving assignments in the form of direct practice with online interaction so that it was easier to understand and corrected directly by lecturers. Furthermore, they suggested apps for more enjoyable English learning related to machine or their field. This study provided an overview of the online English learning process for mechanical engineering students during the pandemic. It is hoped that in the future it will be able to come up with better solutions to the existing challenges.
\end{abstract}

This is an open access article under the CC BY-SA license.

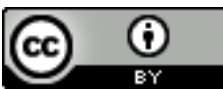

\section{Corresponding Author:}

Yulima Melsipa Lingga,

Department of Mechanical Engineering,

Politeknik Negeri Tanah Laut,

Jl. Ahmad Yani Km 6 Desa Panggung Kec Pelaihari, Kab. Tanah Laut Kalimantan Selatan.

Email: melsi@politala.ac.id

\section{INTRODUCTION}

The condition of the world that is being hit by a pandemic has made many changes in all aspects, including learning. In Indonesia, there is also an exchange of learning processes that were previously face-toface, into online learning. English is a foreign language that requires extra effort to master it. No exception for mechanical engineering students at the Tanah Laut State Polytechnic, South Kalimantan.

Mechanical engineering students at the Tanah Laut State Polytechnic have so far prioritized practical learning rather than just theory. English language learning is designed to meet the needs of students in everyday applications, such as role-play, games and even group learning for project-based learning. Thus, students are more able to absorb the material and apply it directly, either by direct practice with their friends or lecturers.

Basically, the use of technology for learning English is very useful. Munawwarah (2015) in her reseach found that technology could help teachers or instructors to provide learning materials that were 
effective, fun, and interesting. The use of technology is also able to help students learn independently or motivate students to study on their own [1]. The English curriculum has predominantly applied technology to enhance the context of learning and teaching and solve possible challenges. For example, many language classrooms have adopted the latest technologies such as online presentations and online applications [2].

The critical situation that occurred during the pandemic had made schools closed and learning shifted to online learning. This is where the role of technology is needed to help the community, especially schools. Therefore, the integration of technology is very important during this period to help teachers around the world to connect with students and continue the teaching and learning process [3]. But it cannot be denied, in addition to the positive impacts, there are also negative impacts that are felt when learning online. These are the challenges faced by students and educational institutions, including students' parents. Therefore, this study tried to explore what challenges were faced by mechanical engineering students in learning English online during the pandemic. Then what the suggestions were given to overcome these challenges.

Like many other aspects of life, the COVID-19 or coronavirus pandemic has had a serious impact on students, instructors and educational institutions around the world [4]. The pandemic has caused all educational institutions such as schools and universities to be closed to avoid direct contact and implement social distancing [5]. However, changing from a conventional learning system to a virtual distance learning system cannot be done overnight [2]. Of course, this rapid transformation related to the various obstacles and challenges that are currently faced [6]. But since no one knows when this pandemic will actually end, educational institutions around the world have decided to take advantage of the technical resources that are already available to create learning materials for all levels of education. The readiness of students and instructors in facing online learning generally varies depending on how the learning practices are given and the variety of student learning environments [7]. Student learning environment plays an important role in the implementation of online learning.

Online learning can run well and effectively in countries that are already advanced in terms of digital [8]. However, not all Indonesians are digitally literate. This also happened to mechanical engineering students at the Tanah Laut State Polytechnic. There are still some students who are not proficient in using laptops or computers. There are even some who still do not have their own laptop. Of course, this condition affects the virtual or online learning process. Students who access the internet through smartphones are unable to take advantage of online learning because a significant amount of online content is not accessible via smartphones [2].

Furthermore, in order to make online learning programs run well, educators are needed to provide material through technology. This requires educators to have the ability to use good technology for a more interesting learning process. Students also required to be able to self-regulate. Being able to manage themselves well really helps them to make decisions in the independent learning process during virtual learning [9]. Some competencies are needed to stay involved in online learning. That competencies required include communication skills, technological competence, provision of information feedback, administrative skills, responsiveness, monitor learning, and provide student support [10]. Communication skill, educators are expected to be able to build good communication between students and between educators and students. This is very important in directing students to stay concentrated while studying online. Good communication is also needed for the delivery of material so that all students can easily understand the material presented. Technological competence in this regard is also very important. Technology-based knowledge is needed when learning online. Both educators and students must have knowledge of technology to facilitate the teaching and learning process. But what happens sometimes there is a skill gap between educators and students. For this reason, both educators and students must maximize their technological capabilities.

In 2020, many researchers examined the validity and effectiveness of distance learning, including what obstacles were encountered during the teaching and learning process. Some of them were; Adnan and Anwar [2] examined from a student's perspective the influence of online learning. They found that online learning for middle and high school students did not produce the expected results in Pakistan. This is because Pakistan is not so developed in terms of technology. The difficulty of educators and students connecting to the internet was also an obstacle due to financial problems. Likewise Aminullah et al. (2019) observed that some teachers have positive attitudes towards ICT, but others still face many problems such as lack of ICT equipment lack of support from institutions, as well as lack of adequate training.

Nartiningrum and Nugroho [7] in their research on the challenges faced by EFL learners during online learning found that in general the internet signal was unstable and there was a lack of interaction between students and teachers during the learning process. Rifiyanti [9] showed different results in her research on student perceptions of learning English online during a pandemic. She surveyed 108 students in the management and information program at the Kosgoro, Institute of Business and Informatics. The results found that in general online learning could take place effectively. Students can interact with lecturers smoothly. They were also able to understand and absorb the material taught well. Furthermore, from the results of her research,

Online English Learning for Mechanical Engineering Students during the Pandemic: Challenges and Suggestions 
it was also found that $93.5 \%$ of respondents thought that lecturers had the ability and proficiency in using technology in delivering material online.

The use of technology in the process of learning English is very helpful. This is evidenced by several studies, such as that conducted by Lee (2019). In his research, it was stated that the use of IDLE (Informal Digital Learning of English) in learning was very effective and efficient in terms of vocabulary acquisition. Kirovska-Simjanoska [14] also stated in their research that students like learning in class and interacting with others, but they argue that the use of technology is more effective and efficient when learning certain course in English. Nugroho and Atmojo [15] in their research also proved that social networking sites such as Facebook or Instagram were efficient means to improve students' writing skills. From the results of this study, it can be concluded that if technology is used properly it will greatly assist the teaching and learning process of English.

But the current education system is very different. Previously, students were still using blendedlearning, now they must be completely online or distance learning. That's why this research wants to know whether learning English during online-learning is effective or not, especially for mechanical engineering students at the Tanah Laut State Polytechnic. What were the challenges experienced by students, as well as what suggestions were given to meet their English learning needs.

\section{RESEARCH METHOD}

This research was conducted in Indonesia, precisely at the Tanah Laut State Polytechnic, South Kalimantan. Tanah Laut State Polytechnic is currently the only university in Tanah Laut Regency. Tanah Laut State Polytechnic is a vocational polytechnic that prioritizes practicum more than theory. On this basis, the author chose the Tanah Laut State Polytechnic to be the research site. The selected participants are firstsemester students of mechanical engineering. There were 31 students who were purposely selected and two of them were female. They were chosen because the author is one of the lecturers in the department. Making it easier to control each stage of the research. They experienced fully online English Learning since the very first time they became students in Tanah Laut State Polytechnic. Furthermore, communication was also better in data retrieval.

This research design uses descriptive qualitative research. Descriptive qualitative research is research whose data is obtained in the form of a series of words or pictures, rather than numbers. Most qualitative research studies about the meaning of people's lives, such as things experienced in real-world conditions [12]. In this case, the researcher examined the lives of students who study English online during the pandemic. To obtain data, the researcher used written reflections to be filled in by the participants and also semi-structured interviews. Written reflection is a template for a written story that only contains questions and/or instructions and an empty space for answers. This type of instrument really helps researchers to get more in-depth and dense data because participants can clearly and freely write down everything they feel. This makes the data obtained more accurate, rich, and broad because participants have plenty of time to express their thoughts or ideas and beliefs [13]. In addition, semi-structured interviews were used to gain a more detailed understanding of the responses of each participant which they put into written reflections.

At the time of collecting this data, the researcher used google form as the media. Questions were sent to students via google form because there was no face-to-face learning during the pandemic. Questions were given in Indonesian and answered in Indonesian as well. The aim of the researcher, in this case, was for students to be freer to express their thoughts without feeling burdened with using the wrong English. Mechanical engineering students in general have not been able to use English fluently. This was a question sheet in a google form that was sent to students.

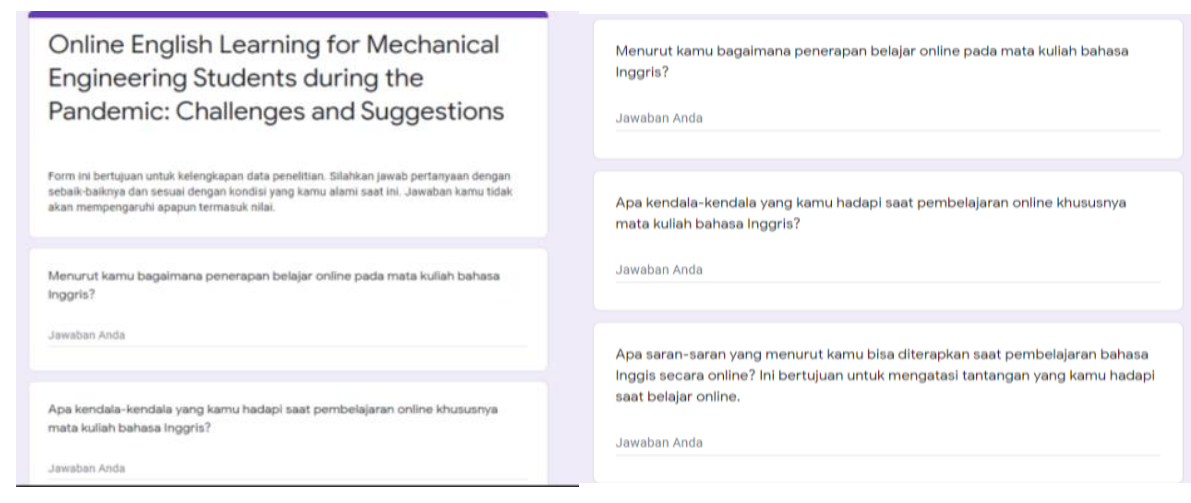

Figure 1. Form of Questions for written reflection 


\section{Data Collection and Data Analysis}

First of all the researcher informed the students that they would receive questions via a google form. The researcher also informed that the purpose of this form was for research data purposes. The questions were written reflections. After about two weeks, 31 students (named S1 - S31) returned their answers. After receiving the answers from the written reflection, after that, the researchers began to conduct semi-structured interviews to find out more about the answers they wrote. The interview was conducted through the Google Meet platform. Every week about five or six students are interviewed. So that about six weeks later all of the students finished being interviewed. So that the interview data can still be seen and heard, the interview was recorded by the researcher.

When analyzing the existing data, the researcher carefully reviewed the data from both written reflection and semi-structured interviews. While analyzing the data, the researcher then did the coding to minimize the answers that did not fit the theme. This coding was meant to get valid data and eliminate unnecessary things. After that, the researchers reviewed, compared, and integrated the data that had been obtained from written reflection and semi-structured interviews. This stage led to the final data analysis and conclusion.

\section{RESULTS AND DISCUSSION}

From the results of data analysis, various answers were found, both from written reflection and semistructured interviews. The data was then divided into two parts, namely an explanation of the results about the challenges faced during online English learning and the second is the suggestions given as solutions to answer the existing challenges.

\subsection{The Challenges during Online English Learning}

One of the obstacles or challenges faced by students when studying online was an unstable internet network. For instance, S15 shared his experiences while studying online as below,

The challenge that I experienced while studying online was the unstable internet network where I lived. During English class, I often leave the Google Meet room because the network is often broken. This made me unable to follow the class well. Sometimes I didn't even go to class because I couldn't connect to the internet. At my house, there is no Wi-Fi so I only rely on internet quota from my cellphone to study.

Some students said that sometimes in the middle of online learning they ran out of internet quota so they had to find a way to re-join learning. Some have to find outlets to fill their internet quota and it's quite far from where they live. There are also those who then join friends who still have quotas so that they can take part in online learning. Such as the response of one participant named S7,

While learning English online, what I often experience is running out of internet quota in the middle of learning. This made me miss the material presented. Sometimes I had to go to find the nearest outlet to fill my quota. Especially if there was an assignment that must be completed that day. Sometimes if I didn't have money to fill my quota then I could continue my studies that day.

S2 also expressed something that was almost similar to the opinion above,

When I study online I often run out of internet quota. If I have money, then I can fill the quota again. But if at that time I didn't have money, then I often joined using a cell phone of a boarding friend that was in the same class as me to be able to continue studying.

Some students stated that learning English online during this pandemic made them a little bored because there was no direct interaction or practice. They found it difficult to understand and apply the material presented if they only study on their own.

Sometimes I get bored quickly learning English if I'm alone. I find it difficult to understand the material if there is no direct practice or interaction with classmates. This makes me sometimes not focus while studying. (S12 written reflection)

What attracted attention was that one of the participants or students, namely S23 only wrote one sentence on the written reflection sheet.

Online English Learning for Mechanical Engineering Students during the Pandemic: Challenges and Suggestions 


\section{English courses are boring. (S23 written reflection)}

It turned out that after doing the interview, it was discovered that he basically didn't like English because it was difficult for him. He found it difficult to understand when the lecturer gives the material and explains in English. He was unable to understand. He also added that if the learning was done offline, he would understand better because there was social interaction by having direct discussions or direct practice with friends.

There were also some students who said that they didn't have a laptop and only access learning and do assignments through their cellphones. This made them a little difficult in the process of working on English assignments. They had to borrow a friend's laptop first to be able to do their assignments. In the end they were late to collect the assignments. An example is the statement written by S27 below.

I don't have a laptop to study online yet. So I only use my cellphone to be able to join while studying online. That's why when I do English assignments I'm often late to collect them because I have to borrow a friend's laptop first to be able to work on and collect them. Sometimes I work by writing answers on paper and then taking photos to send to Google Classroom. If the task is to make videos, then I have trouble editing and sending it if only from my cellphone.

Almost the same thing also expressed by the S11 as follow,

I don't have a laptop so it's not optimal in learning English online. I only use my cellphone. So when doing English assignments, it's a little difficult especially if the task is to make videos. I have to borrow a friend's laptop to access learning who can't use a cellphone.

Some stated that they lacked technology skills, or lacked digital literacy, especially in English. They were still not able to master the application used so they were constrained in the online learning process or when doing tasks such as editing and uploading videos.

I like to learn English but sometimes I have trouble doing assignments. I have not mastered all the applications and learning media used. For example when I want to edit a video and upload it on social media. I also still don't understand how to use the menus on my laptop. (S10 written reflection)

These are the obstacles or challenges that students often face when learning English online in general. If an outline is drawn, then there are five challenges experienced as set out in the following table,

\begin{tabular}{|l|l|c|}
\hline No & Challenges during Online English Learning & $\begin{array}{c}\text { Numbers of } \\
\text { Participants }\end{array}$ \\
\hline Ch.1 & Unstable internet network & 21 \\
\hline Ch.2 & $\begin{array}{l}\text { Running out of internet quota during the online } \\
\text { learning process }\end{array}$ & 8 \\
\hline Ch.3 & $\begin{array}{l}\text { Lack of social interaction such as discussions } \\
\text { and direct English practice with friends }\end{array}$ & 26 \\
\hline Ch.4 & $\begin{array}{l}\text { Don't have a laptop so it's difficult to do the } \\
\text { tasks given }\end{array}$ & 5 \\
\hline Ch.5 & $\begin{array}{l}\text { Have not mastered digital technology or lack } \\
\text { of digital literacy, especially in English }\end{array}$ & 23 \\
\hline
\end{tabular}

Table 1. The Challenges during Online English Learning

The number of participants was taken from student responses from written reflection sheets. Because there were some students who wrote down more than one challenge they have experienced. These types of challenges were then calculated according to their opinion. From this, conclusions can be drawn as shown in the table.

If drawn in the form of a diagram then the result is as follows: 


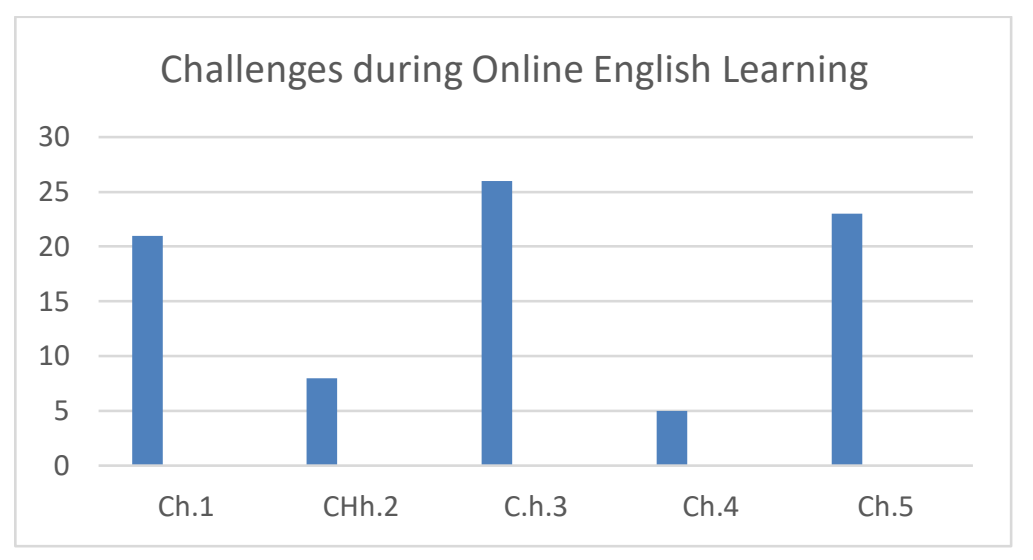

Figure 2. The results of the challenges and the number of participants obtained

From the diagram above, we can conclude that the most common challenge experienced by students during online English learning is the lack of social interaction such as discussions and direct English practice with friends, with 26 responses. Followed by a lack of understanding of students about digital technology as many as 23 responses.

\subsection{Suggestions for Online English Learning}

In addition to writing down the challenges they face, they were also asked to write down the suggestions needed when learning English online. One of the suggestions given was that lecturer used English and Indonesian when explaining the material to make it easier to understand. For example can be seen in the following statement of S22.

I hope that the lecturers can use English and Indonesian as well when delivering the material and explaining the material so that it is easier to understand. I still don't have a lot of English vocabularies, so it's difficult to understand the lessons if most of them are in English.

Almost the same opinion was also conveyed by S16.

Because I am not proficient in English, I suggest that the lecturer use Indonesian when explaining the material so that I can understand.

Some suggested that a learning video be given about the material presented. This is so that they can replay the video if they forget or miss a lesson when they can't attend the English lesson.

I hope there is a video recording of learning when explaining the material. So I can replay the video to better understand each material being taught. This can help me study and do the assignments given. (S11 written reflection)

It would be better if there was a learning video recording about the material given. The video contains the lecturer's explanation of the material. So when the learning process is over, I can still play the video if I forget something. I also don't miss lessons when I'm unable to attend class. (S1 written reflection)

Some students suggested that lecturers provide more reference books related to the material being taught or material related to daily conversation. In this case called practical English. This suggestion is very good because the demand for more books related to the material can enrich their vocabulary in English like the research conducted by Al-Jarf [15][16] indicated that online instruction had an effect on vocabulary development. The references of these books will help them to learn independently.

I need more references to English books that I can read especially about English grammar and structure because I am still weak in this regard. (S31 written reflection) 
My suggestion is that lecturers provide more reading or books that can be studied, especially for daily conversation. Besides that I also want to have a book on English that is special in the field of machinery. (S19 written reflection)

On the other hand, there were also students who suggested that the lecturers should not give too many English assignments. This was because from other courses there were also many assignments that they must complete so that sometimes they got bored with online assignments.

I apologize in advance for saying this, ma'am. My suggestion is that the lecturers don't burden us with many difficult English assignments. We also have to complete many other assignments from other courses. And all must be completed in a short period of time each week. (S18 written reflection)

Please ma'am not to give difficult English assignments. Such as listening to native speakers during an international seminar and summarizing what they have to say. To be honest, ma'am, I can't speak English. It is difficult for me to summarize what the speaker said. Thank you ma'am and sorry in advance. (S24 written reflection)

There were some students who suggested that before delivering learning materials, it was better for the lecturer to first inform what platform or application would be used. This was intended so that students have the preparation and if there were still those who did not know how to use the application, they could still learn first.

My advice ma'am, it is better before learning begins, the lecturer has previously informed us what application will be used during learning later. Sometimes we have not downloaded the application. Or sometimes I don't know how to use the application properly. So that if I have been notified before, I still have time to learn to use the application. Thank you mom. Sorry if you don't like it. (S10 written reflection)

My suggestion is that the lecturer first informs the type of application that will be used before learning. So we can still learn it first. Because if there is an impromptu notification then we may not understand and end up being late for online learning. (S11 written reflection)

These were some suggestions put forward by students in their written reflection sheets. And of course, their opinion was also supported by the interviews conducted. In general, it could be concluded that there were five general suggestions given by them. For more details can be seen in the following table.

\begin{tabular}{|c|l|c|}
\hline No & Suggestions for Online English Learning & $\begin{array}{c}\text { Numbers of } \\
\text { Participants }\end{array}$ \\
\hline Sg.1 & $\begin{array}{l}\text { Lecturers use English as well as Indonesian } \\
\text { when delivering material }\end{array}$ & 25 \\
\hline Sg.2 & $\begin{array}{l}\text { Share learning videos about the material being } \\
\text { taught so that it can be repeated. }\end{array}$ & 13 \\
\hline Sg.3 & $\begin{array}{l}\text { Provide more reference books related to the } \\
\text { material taught and daily practical English }\end{array}$ & 6 \\
\hline Sg.4 & $\begin{array}{l}\text { Lecturers should not give too many English } \\
\text { assignments }\end{array}$ & 4 \\
\hline Sg.5 & $\begin{array}{l}\text { Inform in advance what platforms or } \\
\text { applications will be used during online } \\
\text { learning. }\end{array}$ & \\
\hline
\end{tabular}

Table 2. Suggestions for Online English Learning

The number of participants was taken from student data who provided written reflection sheets. In general, students give more than one suggestion. So each point is added up according to the type of suggestion that is similar so that the number of participants is obtained.

If drawn in the form of a diagram then the result is as follows: 


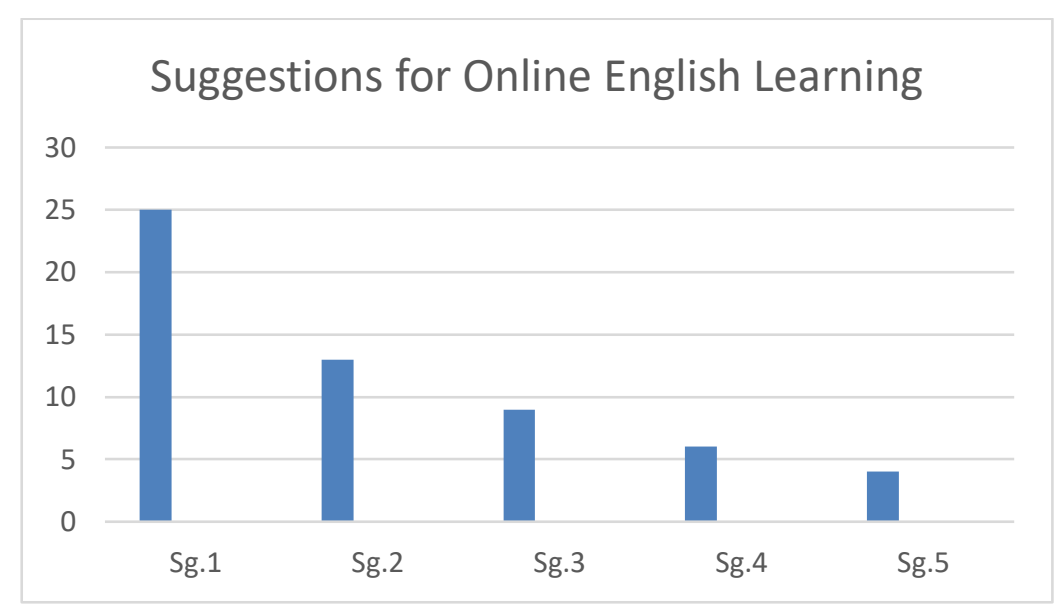

Figure 3. The results of the suggestions given and the number of participants obtained

From the diagram above, it can be concluded that the advice given in general is that lecturers use English as well as Indonesian while providing learning material, which is as many as 25 responses. Then the second is to share learning videos about the material being taught or material about daily practical English, which is as many as 13 responses.

\section{CONCLUSION}

By using descriptive qualitative method, the results obtained that there are as many as five challenges faced by students during online English learning. This conclusion was drawn from the written reflection responses that were distributed to them. The biggest challenge that most of them face is the lack of social interaction in the form of direct discussion and practice. This is because learning is completely online. Basically, they like offline learning and can discuss directly with lecturers and classmates. According to them, online learning is less than optimal and less effective as a whole for English lessons. It can also be concluded that the unstable internet network is a barrier for them to study online.

From the results of the study it can also be concluded that there are five responses which are suggestions given to meet their English learning needs. One of them the most is that they suggest that when learning lecturers can use English as well as Indonesian. This could be due to their lack of vocabulary in English. So often they do not understand about the material. In general, mechanical engineering students are still below the standard regarding English language skills, so this is also an obstacle faced by English lecturers.

\section{ACKNOWLEDGEMENTS}

The researcher expresses his deepest gratitude to the first-semester students of the Politeknik Negeri Tanah Laut who have participated in this research. 


\section{REFERENCES}

[1] E. Apriani, D. Supardan, E. Sartika, S. Suparjo, and I. N. Hakim, “Utilizing Ict To Develop Student'S Language Ethic At Islamic University,” POTENSIA J. Kependidikan Islam, vol. 5, no. 1, p. 1, 2019, doi: 10.24014/potensia.v5i1.6279.

[2] M. Adnan, "Online learning amid the COVID-19 pandemic: Students perspectives," J. Pedagog. Sociol. Psychol., vol. 1, no. 2, pp. 45-51, 2020, doi: 10.33902/jpsp.2020261309.

[3] S. Khatoony and M. Nezhadmehr, "EFL teachers' challenges in integration of technology for online classrooms during Coronavirus (COVID-19) pandemic in Iran," AJELP Asian J. English Lang. Pedagog., vol. 8, no. 2, pp. 1-16, 2020, [Online]. Available: https://ojs.upsi.edu.my/index.php/AJELP/article/view/3523.

[4] Mailizar, A. Almanthari, S. Maulina, and S. Bruce, "Secondary school mathematics teachers' views on elearning implementation barriers during the COVID-19 pandemic: The case of Indonesia," Eurasia J. Math. Sci. Technol. Educ., vol. 16, no. 7, 2020, doi: 10.29333/EJMSTE/8240.

[5] C. M. Toquero, "Challenges and Opportunities for Higher Education amid the COVID-19 Pandemic: The Philippine Context," Pedagog. Res., vol. 5, no. 4, p. em0063, 2020, doi: 10.29333/pr/7947.

[6] J. C. A, K. B. B, and S. L. H, "COVID-19: 20 countries' higher education intra-period digital pedagogy responses,” J. Appl. Learn. Teach., vol. 3, no. 1, 2020, doi: 10.37074/jalt.2020.3.1.7.

[7] N. Nartiningrum and A. Nugroho, "Online Learning amidst Global Pandemic: EFL Students' Challenges, Suggestions, and Needed Materials," ENGLISH Fr. Acad. J. English Lang. Educ., vol. 4, no. 2, p. 115, 2020 , doi: 10.29240/ef.v4i2.1494

[8] G. Basilaia and D. Kvavadze, "Transition to Online Education in Schools during a SARS-CoV-2 Coronavirus (COVID-19) Pandemic in Georgia," Pedagog. Res., vol. 5, no. 4, 2020, doi: 10.29333/pr/7937.

[9] H. Rifiyanti, "Learners' Perceptions of Online English Learning during COVID-19 Pandemic," Scope J. English Lang. Teach., vol. 5, no. 1, p. 31, 2020, doi: 10.30998/scope.v5i1.6719.

[10] C. Roddy et al., "Applying Best Practice Online Learning, Teaching, and Support to Intensive Online Environments: An Integrative Review," Front. Educ., vol. 2, no. November, pp. 1-10, 2017, doi: 10.3389/feduc.2017.00059.

[11] D. Kirovska-Simjanoska, "Digital vs in-Person Learning Environment in ESP Classrooms: Let the Students Decide," SEEU Rev., vol. 14, no. 1, pp. 36-68, 2019, doi: 10.2478/seeur-2019-0004.

[12] A. Nugroho and A. E. P. Atmojo, "Digital Learning of English Beyond Classroom: Efl Learners' Perception and Teaching Activities,” JEELS (Journal English Educ. Linguist. Stud., vol. 7, no. 2, pp. 219-243, 2020, doi: 10.30762/jeels.v7i2.1993.

[13] R. K. Yin, $\square$ Qualitative Research from Start to Finish, second edition. 2016.

[14] T. Hollweck, "Robert K. Yin. (2014). Case Study Research Design and Methods (5th ed.). Thousand Oaks, CA: Sage. 282 pages.," Can. J. Progr. Eval., vol. 1, no. 2014, pp. 108-110, 2016, doi: 10.3138/cjpe.30.1.108.

[15] R. Al-Jarf, "Teaching vocabulary to EFL college students online," CALL-EJ Online, vol. 8, no. 2, pp. 1-16, 2007, [Online]. Available: https://www.researchgate.net/publication/267370620\%250. 


\section{BIOGRAPHIES OF AUTHORS (10 PT)}

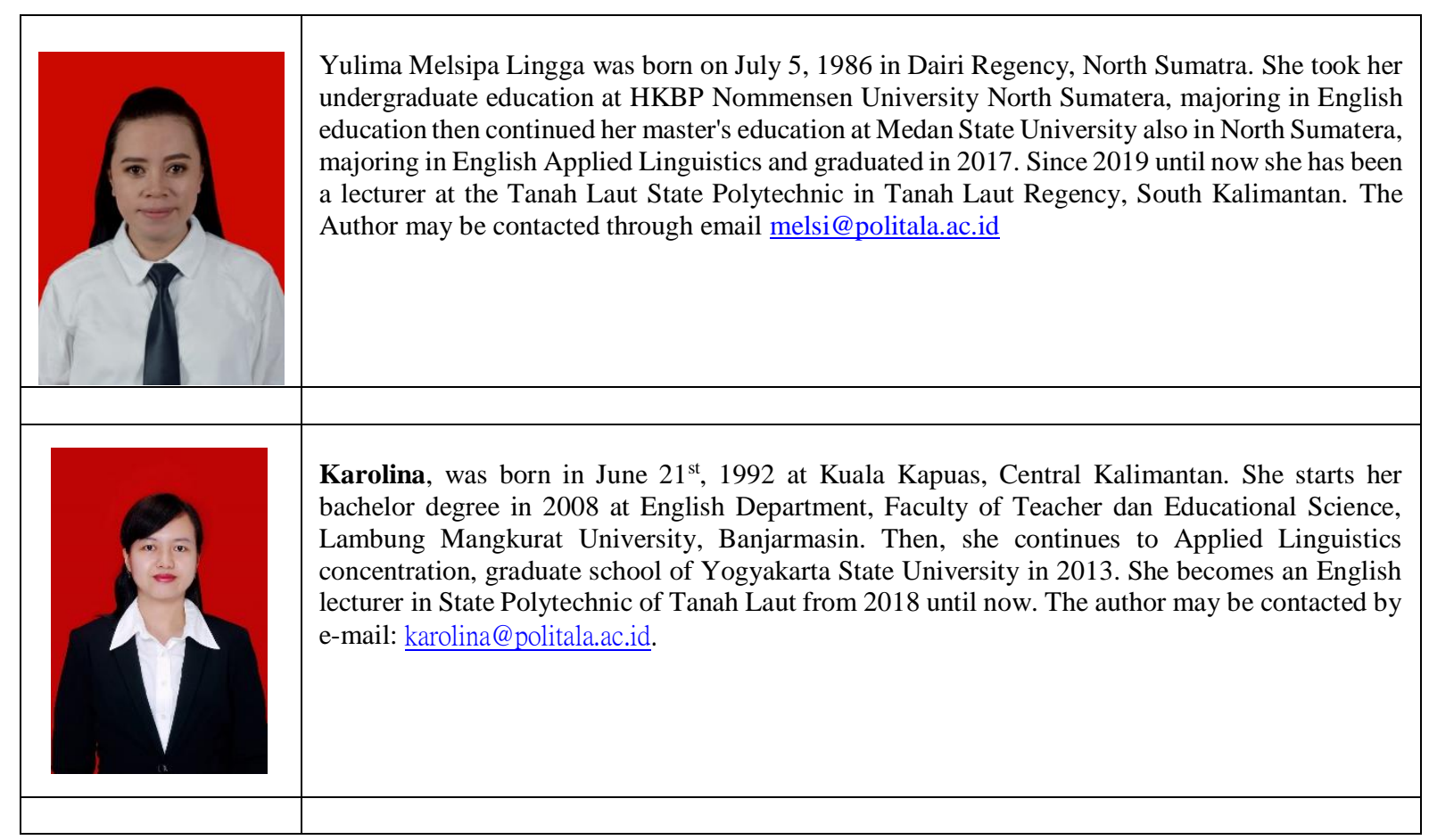

